\title{
Could packing and pelleting keep the quality of tobacco seeds during storage? ${ }^{1}$
}

\author{
Maria Laene Moreira de Carvalho², Camila Aparecida Lopes²*, \\ Ana Maria Pereira Ribeiro ${ }^{2}$, Michelle Conceição Vasconcelos ${ }^{3}$
}

\begin{abstract}
The packaging, used to maintain the seeds during storage, is extremely important in their conservation. Seeds from the cultivar BAT 2101 were used in order to evaluate the effect of packaging on the conservation of the quality of bare and pelleted tobacco seeds stored in the long-term. After characterization of the lot profile, the seeds were stored for 180 , 360,540 , and 720 days under ambient conditions at $25^{\circ} \mathrm{C} \pm 2$ and $62.8 \%$ relative humidity in cotton bags, aluminum cans, laminated envelopes, plastic envelopes and paper envelopes. The seed quality throughout the storage in the different packages was determined by the water content and germination tests, first germination count, germination speed index, initial and final emergence and emergence speed index. The aluminum can packaging keeps the quality of bare and pelleted tobacco seeds for a period of 720 days. Up to 360 days of storage, there was a decrease in the dormancy of bare and pelleted seeds with an increase in deterioration after this period, except for those kept in the aluminum can packing.
\end{abstract}

Index terms: Nicotiana tabacum, conservation, germination, vigor.

\section{Embalagem e pelotização poderiam manter a qualidade de sementes de tabaco durante o armazenamento?}

\begin{abstract}
RESUMO - A embalagem utilizada para manter as sementes durante o armazenamento é de grande importância na sua conservação. O efeito das embalagens na conservação da qualidade de sementes nuas e pelotizadas de tabaco da cultivar BAT 2101 foi avaliado no armazenamento a longo prazo. Após a caracterização do perfil do lote, as sementes foram armazenadas por 180, 360, 540 e 720 dias em condições de ambiente a $25^{\circ} \mathrm{C}$ e umidade relativa de $62,8 \%$, em sacos de algodão, latas de alumínio, envelopes laminado, envelopes plástico e envelopes de papel. A qualidade das sementes ao longo do armazenamento nas embalagens foi determinada pelo teor de água e pelos testes de germinação, primeira contagem de germinação, índice de velocidade de germinação, emergência inicial e final e índice de velocidade de emergência. A embalagem lata de alumínio permite manter a qualidade das sementes de tabaco nuas e pelotizadas por um período de 720 dias. Até os 360 dias de armazenamento houve diminuição da dormência das sementes nuas e pelotizadas e após esse período um aumento da deterioração, exceto para as mantidas em latas de alumínio.
\end{abstract}

Termos para indexação: Nicotiana tabacum, conservação, germinação, vigor.

\section{Introduction}

Tobacco growing is the most important non-food agricultural crop worldwide and contributes substantially to the economy of more than 150 countries. Brazil is the largest exporter and the second largest producer of Nicotiana tabacum L. around the world, after only China (Sinditabaco, 2018), besides being the largest exporter of seeds worldwide.

${ }^{1}$ Submitted on 01/29/2018. Accepted for publication on 06/19/2018. ${ }^{2}$ Departamento de Agricultura, Universidade Federal de Lavras, Caixa Postal 3037, 37200-000 - Lavras, MG, Brasil.
Tobacco belongs to the family Solanaceae, genus Nicotiana, an autogamous, herbaceous annual plant with an approximate cycle of 190 days and it is propagated by seeds. However, one of the obstacles found in tobacco cultivation is related to the size, shape and weight of seeds, which hinders the sowing. Each gram of seed contains about 16,000 units (Brasil, 2009) and for this reason, commercial seeds are pelletized to increase size and facilitate sowing (Caldeira et al., 2016).
${ }^{3}$ Departamento de Engenharia Agronômica, Universidade Federal do Sergipe, Caixa Postal 49100-000 - São Cristóvão, SE, Brasil.

*Corresponding author <camilalopes_sjc@hotmail.com> 
The use of pelleted seeds may have some problems, since the pellet formed around the seed can affect its performance during germination (Carvalho and Novembre, 2011). In the literature, there are some research demonstrating that bare seeds of tobacco germinate faster than pelleted seeds (Carvalho and Novembre, 2011; Caldeira et al., 2016). Moreover, tobacco seeds are considered positive photoblastics (LeubnerMetzger and Meins, 2000) and the coating may induce a photoinhibition, negatively affecting seed germination. Additionally, there is still little information available on seed pelletizing, especially in relation to pellet composition and performance of seed pellets during storage (Oliveira et al., 2003; Pereira et al., 2011).

The species Nicotiana tabacum produces long-lived seeds, which can be stored for years, as long as conditions of low humidity and low temperature could be maintained in storage (Leubner-Metzger, 2002). The type of packaging, the relative humidity of the environment, moisture content of the seeds and the temperature of seeds during storage are highly relevant in maintaining their viability and vigor. However, there is very little information in the scientific literature that indicates the best form of conservation of these seeds (Lee et al., 2010; Costa et al., 2012; Agacka et al., 2013; Caldeira et al., 2016). In this way, the aim of the present study was to verify the best type of packaging for preserving the physiological quality of bare and pelleted tobacco seeds throughout long-term storage.

\section{Material and Methods}

The tobacco seeds used were from cultivar BAT 2101 (Burley varietal group), harvested in Rio Negro, PR, Brazil, in the 2013/2014 harvest, pelletized or not. The pelletizing was performed according to the standard established by the seed producing company.

The characterization of the seed lot profile was performed through the determination of the water content and the tests of first germination count, germination, germination speed index, initial and final emergence, emergence speed index and electrical conductivity.

Seeds were stored under ambient conditions for 720 days, where the average temperature was $25^{\circ} \mathrm{C} \pm 2$ and the relative humidity was $62.8 \%$. Seeds were stored in a permeable package (cotton bag and paper envelope), semi-permeable package (plastic envelope) and impermeable package (aluminum can and laminated envelope). Each package contained $3 \mathrm{~g}$ of seeds, being the package capacity variable according to the marketing standard.

The seed quality evaluation was performed every 180 days of storage in individual packages for each evaluation period.
The water content of seeds was determined and the following tests were performed: germination, first germination count, germination speed index, initial and final emergence, emergence speed index and electrical conductivity (only for bare seeds).

In the germination test, three replications of 100 seeds were used, which were sown on a blotting paper substrate, moistened with $\mathrm{KNO}_{3}$ solution $(0.2 \%)$ in an amount equivalent to 2.5 times the weight of the dry substrate, in an acrylic gerbox with lid $(11 \times 11 \times 3.5)$. The seeds were kept in a germination chamber with alternating temperature between 20 and $30^{\circ} \mathrm{C}, 8 \mathrm{~h}$ photoperiod and light intensity of 2,000 lux (Brasil, 2009). The number of germinated seeds was evaluated daily in order to obtain the germination speed index described by Maguire (1962). The germination results were expressed as percentage of normal seedlings with evaluation at seven days after sowing in order to obtain the first germination count, and at 16 days for germination (Brasil, 2009).

The emergence test was conducted in a float system, with sowing performed on Carolina ${ }^{\circledR}$ commercial substrate, previously moistened (approximately $1 \mathrm{~L}$ of water per $\mathrm{kg}$ of substrate), placed in acrylic plates with individualized cells perforated with 100 cells each. After sowing, the acrylic plates were kept floating on a water depth of approximately $2 \mathrm{~cm}$ and kept in germination chamber with a temperature of $30{ }^{\circ} \mathrm{C} \pm 2$. The evaluation of the number of seedlings with the first pair of leaves was performed daily in order to obtain the emergence speed index (Maguire, 1962). Counts were performed on the seventh day in order to obtain the initial emergence, and on the 16th day for final emergence, these data were expressed as percentage.

The experimental design was a completely randomized and the statistical analyses performed using the SISVAR software (Ferreira, 2011). The data were interpreted statistically through analysis of variance in a $5 \times 5$ factorial design, an array of five types of packaging (cotton bag, aluminum can, laminated envelope, plastic envelope and paper envelope) and five storage periods $(0,180,360,540$ and 720 days) for each type of seed (bare and pelleted).

\section{Results and Discussion}

Bare seeds - Throughout the 720 days of storage, the bare seeds of tobacco showed slight oscillations in the water content, regardless of their packaging. The highest variation $(1.86 \%)$ was observed for seeds stored in paper envelope. This behavior is explained by the environmental variation at the storage site, which was $25 \pm 2{ }^{\circ} \mathrm{C}$ temperature and $62.8 \%$ relative humidity. According to Silva et al. (2010), regardless of the species, the moisture content of seeds 
stored in permeable packages undergo more influence from the climatic conditions of the storage site than those stored in semi-permeable and impermeable packages, as observed in the present study. Changes in the water content of the seeds during storage are also expected, as this may still vary depending on the chemical composition of the seeds (Belmiro et al., 2010).

According to the results of the analysis of variance for bare seeds of the cultivar 'BAT 2101', there was significant interaction between the factors Packaging*Period for the tests first germination count (FGC) and germination speed index (GSI). For germination (G), only the period factor was significant. Thereby, it was observed that the storage of bare seeds in different packages affected significantly the vigor, but not the seed germination. Vigor tests are generally more sensitive in the evaluation of physiological quality of the seeds than the germination test because, according to Amaro et al. (2015), this test shows limitations by providing results that overestimate the physiological potential of seeds, once it is performed under conditions considered as optimal.

The germination of tobacco seeds remained constant until 360 days, a slight decrease was observed after this period (Figure 1). This result corroborates those obtained by Agacka et al. (2013) for tobacco seeds stored for 12 years under environmental conditions $\left(20^{\circ} \mathrm{C}\right.$ and $50 \%$ relative humidity), which observed a higher germination rate in the first year, with a sharper decrease throughout storage.

Regarding the vigor, evaluated by the first germination count (Table 1), a great variation of results is observed in the different evaluation periods. However, when the seeds were stored in aluminum cans, they presented results equal or greater than those stored in other packages in all evaluation periods. It can be observed in that the bare seeds stored in aluminum can maintained their physiological quality during the 720 days. Throughout the storage, there was a tendency to increase the germination speed of seeds in the other packages until approximately 452 days, but the percentage of normal seedlings in the first germination count decreased after that period, according to the regression equation ( $\mathrm{y}=$ $\left.88.171429+0.016799 x-0.000017 x^{2} ; R^{2}=81.67\right)$. Probably, the increase of germination speed observed for this period was caused by a dormancy overcoming of the seeds, since the tobacco seeds physiological dormancy is considered to be not deep, induced by the exogenous $\mathrm{ABA}$ and the mechanical resistance exerted by the endosperm-test (Leubner-Metzger, 2002; Onelli et al., 2017).

There was variation in the germination speed index of seeds in the different packaging (Table 2). The germination speed of seeds was similar regardless of the packaging until 360 days, however, the seeds stored in laminated envelope and aluminum can obtained the highest GSI at 540 days, which was maintained for the seeds stored in the can at 720

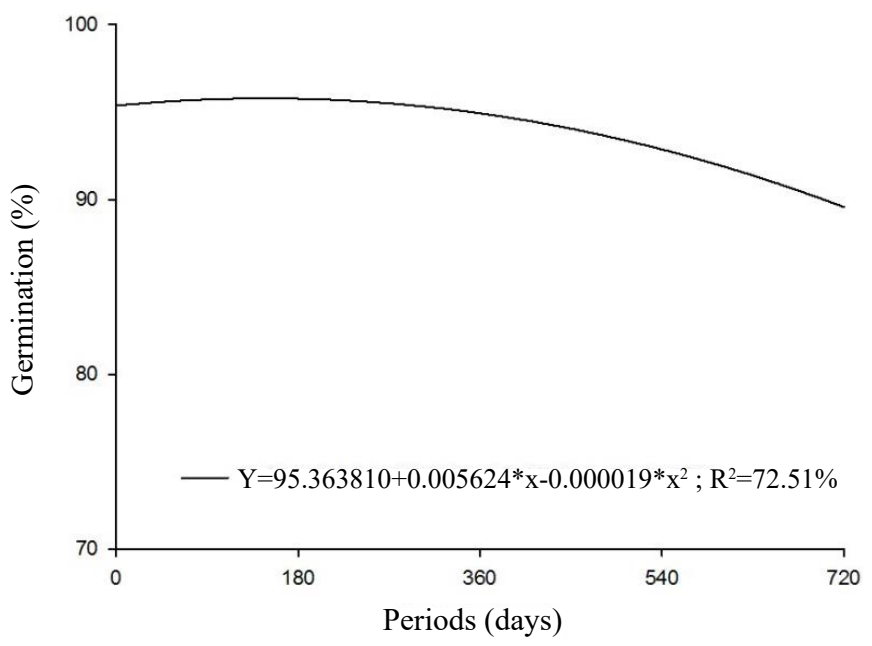

Figure 1. Average values of germination $(\mathrm{G} \%)$ as a function of the storage of bare tobacco seeds from the cultivar BAT 2101, kept in different packages.

Table 1. Average values of first germination count (FGC) of bare tobacco seeds from the cultivar BAT 2101, stored for 720 days in different packages.

\begin{tabular}{lccccc}
\hline \multirow{2}{*}{ Packaging } & \multicolumn{5}{c}{ Periods (days) } \\
\cline { 2 - 6 } & 0 & 180 & 360 & 540 & 720 \\
\hline Cotton & $86 \mathrm{aB}$ & $96 \mathrm{aA}$ & $93 \mathrm{aA}$ & $84 \mathrm{bB}$ & $85 \mathrm{aB}$ \\
Aluminum can & $89 \mathrm{aA}$ & $91 \mathrm{aA}$ & $92 \mathrm{aA}$ & $93 \mathrm{aA}$ & $91 \mathrm{aA}$ \\
Laminated env. & $83 \mathrm{aB}$ & $85 \mathrm{bB}$ & $95 \mathrm{aA}$ & $90 \mathrm{aA}$ & $85 \mathrm{aB}$ \\
Plastic env. & $72 \mathrm{bB}$ & $88 \mathrm{bA}$ & $94 \mathrm{aA}$ & $85 \mathrm{bA}$ & $89 \mathrm{aA}$ \\
Paper env. & $76 \mathrm{bC}$ & $93 \mathrm{aA}$ & $91 \mathrm{aA}$ & $86 \mathrm{bB}$ & $84 \mathrm{aB}$ \\
\hline \multicolumn{1}{c}{$\mathrm{CV}(\%)$} & & 5.00 & \\
\hline
\end{tabular}

Averages followed by the same lowercase letter (in columns) or the same capital letter (in rows) do not differ by the Scott-Knott test at $5 \%$ of probability.

Table 2. Average values of germination speed index (GSI) of bare tobacco seeds from the cultivar BAT 2101, stored for 720 days in different packages.

\begin{tabular}{lccccc}
\hline \multirow{2}{*}{ Packaging } & \multicolumn{5}{c}{ Periods (days) } \\
\cline { 2 - 6 } & 0 & 180 & 360 & 540 & 720 \\
\hline Cotton & $14 \mathrm{aB}$ & $18 \mathrm{aA}$ & $15 \mathrm{aB}$ & $14 \mathrm{bB}$ & $14 \mathrm{cB}$ \\
Aluminum can & $14 \mathrm{aC}$ & $17 \mathrm{aB}$ & $16 \mathrm{aB}$ & $16 \mathrm{aB}$ & $19 \mathrm{aA}$ \\
Laminated env. & $14 \mathrm{aB}$ & $17 \mathrm{aA}$ & $16 \mathrm{aA}$ & $15 \mathrm{aB}$ & $17 \mathrm{bA}$ \\
Plastic env. & $13 \mathrm{aC}$ & $17 \mathrm{aA}$ & $15 \mathrm{aB}$ & $14 \mathrm{bC}$ & $17 \mathrm{bA}$ \\
Paper env. & $13 \mathrm{aB}$ & $17 \mathrm{aA}$ & $15 \mathrm{aB}$ & $14 \mathrm{bB}$ & $15 \mathrm{cB}$ \\
\hline \multicolumn{1}{c}{$\mathrm{CV}(\%)$} & & 5.76 & & \\
\hline
\end{tabular}

Averages followed by the same lowercase letter (in columns) or the same capital letter (in rows) do not differ by the Scott-Knott test at $5 \%$ of probability. 
days, confirming the vigor expression already presented in the percentage of first germination count. Several research have demonstrated the superiority of impermeable package for the preservation of quality of some oleaginous seeds, such as tobacco (Queiroga et al., 2009; Cardoso et al., 2012; Pinto Junior et al., 2012). In the second storage period, at 180 days, the seeds stored in the cotton packages, laminated envelope, plastic envelope and paper envelope presented the highest germination speed. With the exception of the seeds kept in aluminum can that maintained their speed of germination increasing until the 720 days.

A significant effect of the storage period on the quality of tobacco seeds was observed in the evaluations: initial emergence (IE), final emergence (FE) and emergence speed index (ESI). For these tests, no effect of the packages on the quality of the bare seed of tobacco was observed.

It can be observed through the initial stand results that seed vigor was altered after 532 days of storage (Figure 2A). Similar results were observed for the final emergence (Figure $2 \mathrm{~B}$ ), with increase of the stand, probably due to the dormancy breaking of seeds up to 534 days, with increased deterioration after that period. This result indicates that the quality of tobacco seeds was reduced after this period regardless of the packaging in which the seeds were stored. Different from Caldeira et al. (2016) who observed that the tobacco seeds from two cultivars maintained their physiological quality during 360 days of storage in a cold chamber $\left(10^{\circ} \mathrm{C}\right)$. The emergence speed index remained constant throughout the storage period, with a value of 16.47 (data not shown).

Pelleted seeds - The water content of pelleted tobacco seeds showed small oscillations throughout the storage, regardless of the packaging, ranging from 1.12 to $2.03 \%$, and was lower than that determined for bare seeds because, in the case of pelleted seeds, it is measured the seed set plus coating, thus affecting the moisture degree of seeds (Carvalho and Novembre, 2011).

According to the results of the analysis of variance for the pelleted tobacco seeds from the cultivar 'BAT 2101', the packaging effect varied as a function of the storage period according to the results of the tests first germination count (FGC), germination (G), germination speed index (GSI), initial stand (IS), final stand (FS) and emergence speed index (ESI). The long-term storage of pelleted tobacco seeds in the different packaging affected both germination and vigor. In Table 3, the average values of percentage of normal seedlings were higher for seeds packed in aluminum cans in the first germination count in four of the five evaluated periods. For the plastic and paper envelopes, the highest percentages were observed only for seeds stored for 180 days. At the end of the storage period, the positive effect of the aluminum can packaging can be observed on the conservation of seeds in relation to the other tested packages. Masseto et al. (2013) also observed the superiority of impermeable packaging to maintain the physiological quality of crambe seeds during long-term storage.
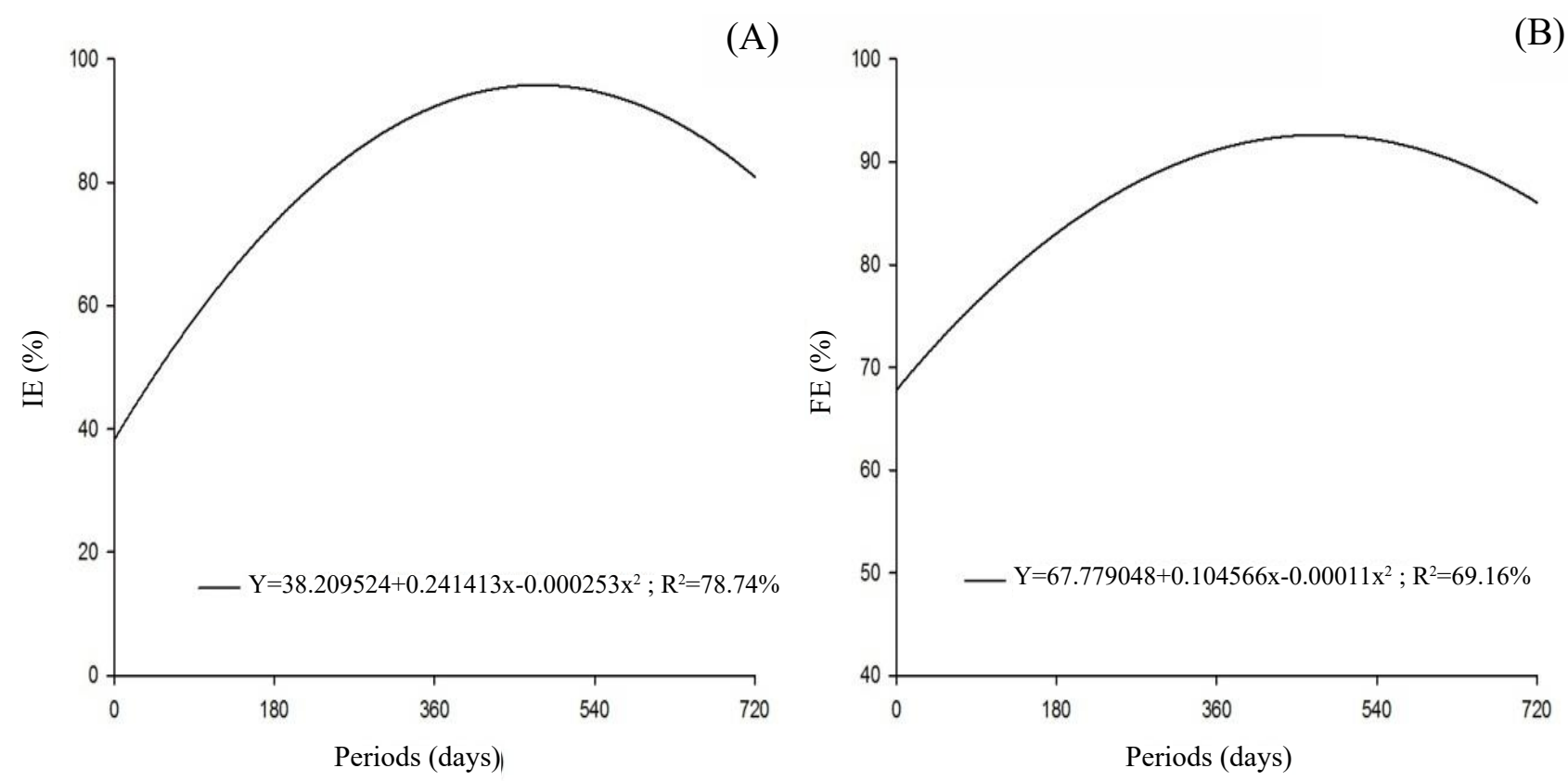

Figure 2. Average values of initial emergence (IE\%) (A), Final emergence (FE\%) (B) and bare tobacco seeds from the cultivar BAT 2101 stored for 720 days. 
In the second storage period, at 180 days, all seeds, regardless of the packaging in which they were stored, had a higher percentage of seedlings in the first germination count than in the other seasons (Table 3). According to Resende et al. (2009) the storage of pelleted seeds at low temperature and in the dark may have increased the synthesis of gibberellins. In positive photoblastic species, such as tobacco, gibberellin may replace light in seed germination and increasing its level during storage may have favored germination.

The germination (Table 4) remained constant regardless of the package in which the seeds were stored up to 540 days. The seeds stored in aluminum cans and cotton bags at 720 days showed superior quality than those stored in the other packages. Germination of the seeds stored in the laminated envelope and plastic envelope packages decreased after the 375 days of storage, as presented in the regression equation ( $\mathrm{y}=87.609524$ $\left.+0.058413 x-0.000096 x^{2} ; R^{2}=98.19 \%\right)$. For the seeds kept in paper envelope, the decrease in germination was verified from 310 days $\left(\mathrm{y}=93.533333+0.023148 \mathrm{x}-0.000057 \mathrm{x}^{2} ; \mathrm{R}^{2}=\right.$ $98.28 \%$ ). For the seeds kept in aluminum can and cotton bag, the germination remained constant throughout the conservation periods $\left(y=90.285714+0.035899 x-0.000042 x^{2}, R^{2}=98.02 \%\right)$. It is emphasized that the deterioration process is inevitable, but may be delayed, depending on the storage conditions and the characteristics of the seeds (Cardoso et al., 2012).

It was observed a great variation of results in the different evaluation periods in the germination of the pelleted tobacco seeds (Table 5). However, when the seeds were stored in aluminum cans, regardless of the evaluation period, they had the equal or better results than seeds stored in other packages. It is also observed that the germination speed results of pelleted seeds were lower than bare seeds. The small seed size and the coating material that prevents the passage of light and makes the emission of the radicle harder has contributed to the slow germination of pelleted tobacco seeds. This result corroborates those described by Caldeira et al. (2016), which worked with bare and pelleted tobacco seeds and observed that the pellet delayed the seed germination process, although it did not adversely affect germination. According to Nascimento et al. (2009), despite the benefits of pelletizing, the seed coating process can affect the germination due to the barrier imposed by the material making it difficult to emit the radicle, the gas exchange, and its diffusion to the environment external to the pellet.

For the seeds stored in the packaging aluminum can and laminated envelope showed an increase in GSI up to 347 days for the latter $\left(\mathrm{y}=8.606381+0.02302 \mathrm{x}-0.000034 \mathrm{x}^{2}\right.$; $\left.\mathrm{R}^{2}=68.15 \%\right)$ and up to 510 days for the first ( $\mathrm{y}=9.03181$ $+0.02098 \mathrm{x}-0.000021 \mathrm{x}^{2} ; \mathrm{R}^{2}=69.26 \%$ ). After this period, the germination speed decreased until the 720 days. However, the seeds stored in plastic envelope, paper envelope and cotton bag showed a decrease in germination speed from 180 days. According to Cardoso et al. (2012), this result is expected, since seeds stored in permeable packages suffer more influence from the atmospheric conditions of the storage site and consequently have their physiological quality more affected than the seeds stored in impermeable packages.

Table 3. Average values of first germination count (FGC \%) of pelleted tobacco seeds from the cultivar BAT 2101 , stored for 720 days in different packages.

\begin{tabular}{lccccc}
\hline \multirow{2}{*}{ Packaging } & \multicolumn{5}{c}{ Periods (days) } \\
\cline { 2 - 6 } & 0 & 180 & 360 & 540 & 720 \\
\hline Cotton & $00 \mathrm{bB}$ & $51 \mathrm{cA}$ & $02 \mathrm{bB}$ & $00 \mathrm{bB}$ & $07 \mathrm{bB}$ \\
Aluminum can & $00 \mathrm{bD}$ & $85 \mathrm{aA}$ & $48 \mathrm{aC}$ & $68 \mathrm{aB}$ & $71 \mathrm{aB}$ \\
Laminated env. & $00 \mathrm{bB}$ & $73 \mathrm{bA}$ & $10 \mathrm{bB}$ & $02 \mathrm{bB}$ & $08 \mathrm{bB}$ \\
Plastic env. & $00 \mathrm{bB}$ & $85 \mathrm{aA}$ & $10 \mathrm{bB}$ & $03 \mathrm{bB}$ & $05 \mathrm{bB}$ \\
Paper env. & $02 \mathrm{aB}$ & $82 \mathrm{aA}$ & $09 \mathrm{bB}$ & $01 \mathrm{bB}$ & $02 \mathrm{bB}$ \\
\hline \multicolumn{1}{c}{$\mathrm{CV}(\%)$} & & & 24.40 \\
\hline
\end{tabular}

Averages followed by the same lowercase letter (in columns) or the same capital letter (in rows) do not differ by the Scott-Knott test at $5 \%$ of probability.

Table 4. Average values of germination (G \%) of pelleted tobacco seeds from the cultivar BAT 2101, stored for 720 days in different packages.

\begin{tabular}{lccccc}
\hline \multirow{2}{*}{ Packaging } & \multicolumn{5}{c}{ Periods (days) } \\
\cline { 2 - 6 } & 0 & 180 & 360 & 540 & 720 \\
\hline Cotton & $90 \mathrm{aA}$ & $95 \mathrm{aA}$ & $94 \mathrm{aA}$ & $92 \mathrm{aA}$ & $88 \mathrm{aA}$ \\
Aluminum can & $90 \mathrm{aA}$ & $96 \mathrm{aA}$ & $98 \mathrm{aA}$ & $92 \mathrm{aA}$ & $95 \mathrm{aA}$ \\
Laminated env. & $92 \mathrm{aA}$ & $96 \mathrm{aA}$ & $97 \mathrm{aA}$ & $97 \mathrm{aA}$ & $75 \mathrm{bB}$ \\
Plastic env. & $87 \mathrm{aB}$ & $96 \mathrm{aA}$ & $95 \mathrm{aA}$ & $92 \mathrm{aA}$ & $80 \mathrm{bC}$ \\
Paper env. & $93 \mathrm{aA}$ & $97 \mathrm{aA}$ & $94 \mathrm{aA}$ & $89 \mathrm{aB}$ & $81 \mathrm{bC}$ \\
\hline \multicolumn{1}{c}{$\mathrm{CV}(\%)$} & & & 4.59 \\
\hline
\end{tabular}

Averages followed by the same lowercase letter (in columns) or the same capital letter (in rows) do not differ by the Scott-Knott test at $5 \%$ of probability.

Table 5. Average values of germination speed index (GSI) of pelleted tobacco seeds from the cultivar BAT 2101, stored for 720 days in different packages.

\begin{tabular}{lccccc}
\hline \multirow{2}{*}{ Packaging } & \multicolumn{5}{c}{ Periods (days) } \\
\cline { 2 - 6 } & 0 & 180 & 360 & 540 & 720 \\
\hline Cotton & $09 \mathrm{aC}$ & $13 \mathrm{bA}$ & $11 \mathrm{bB}$ & $10 \mathrm{bB}$ & $10 \mathrm{bB}$ \\
Aluminum can & $08 \mathrm{aC}$ & $14 \mathrm{aA}$ & $13 \mathrm{aB}$ & $13 \mathrm{aB}$ & $14 \mathrm{aA}$ \\
Laminated env. & $08 \mathrm{bC}$ & $14 \mathrm{aA}$ & $11 \mathrm{bB}$ & $10 \mathrm{bB}$ & $08 \mathrm{cC}$ \\
Plastic env. & $09 \mathrm{aC}$ & $15 \mathrm{aA}$ & $11 \mathrm{bB}$ & $10 \mathrm{bB}$ & $08 \mathrm{cC}$ \\
Paper env. & $09 \mathrm{aC}$ & $14 \mathrm{aA}$ & $11 \mathrm{bB}$ & $10 \mathrm{bB}$ & $08 \mathrm{cC}$ \\
\hline \multicolumn{7}{c}{$\mathrm{CV}(\%)$} & \multicolumn{5}{c}{6.55} \\
\hline
\end{tabular}

Averages followed by the same lowercase letter (in columns) or the same capital letter (in rows) do not differ by the Scott-Knott test at $5 \%$ of probability. 
There was a difference between the quality of the seeds stored in the five packages at different periods for the initial stand (Table 6), being that the averages did not differ before the storage. Only the seeds stored in the aluminum can maintained their quality throughout the storage. The pelleted seeds stored in cotton packages, laminated, plastic and paper envelope had similar behavior during storage, with an increase in vigor up to 383 days, with decrease after that period up to 720 days, according to the regression equation $(\mathrm{y}=7.628571$ $\left.+0.478571 \mathrm{x}-0.000636 \mathrm{x}^{2} ; \mathrm{R}^{2}=94.96 \%\right)$. Regarding the seeds maintained in the aluminum can packaging, the average values of the initial stand were kept increasing throughout the storage, ensuring a greater vigor in relation to the other packages. Oliveira et al. (2003) worked with storage of seed coated of tomato for 720 days in a laminated and paper envelopes, and verified that these seeds maintained their quality in storage regardless of the used packaging.

It was observed that the average values of emergence did not differ among themselves in four of the five evaluated periods, regardless of the packaging in which the seeds were stored (Table 7). A lower percentage of seedlings was observed at the final stand only in the final evaluation period, at 720 days, for seeds stored in plastic envelope and laminated envelope. It was verified that the pelleted tobacco seeds stored in the paper envelope maintained their similar physiological quality during the 720 days. However, the seeds stored in the other packages lost quality after 380 days of storage $\left(\mathrm{y}=82.809524+0.081931 \mathrm{x}-0.000142 \mathrm{x}^{2} ; \mathrm{R}^{2}=\right.$ $94.45)$, as can be observed by the lower number of plants in the final stand in the evaluations performed at 540 and 720 days. The seeds stored in aluminum can presented an increase in the number of plants in the final stand along the storage, thus demonstrating the superiority of impermeable packaging for the conservation of the physiological quality of the seeds. These results corroborate with Oliveira and Costa (2009), which state that the best packaging for seed storage is impermeable.

There was variation in the emergence speed index of seeds stored in the different packaging (Table 8). At the end of the storage period, the positive effect of aluminum can packaging can be observed on the conservation of seeds in relation to the other tested packages due to the higher emergence speed. These results corroborate with those found by Azevedo et al. (2003), which worked with the storage of sesame seeds and observed that the greatest showed vigor was in seeds packed in impermeable packages.

For the seeds stored in the packaging cotton bag, laminated envelope, paper envelope and plastic envelope, the emergence speed is increased until 350 days, with decrease of ESI after this period up to the 720 days, according to the regression equation $\left(y=9.838571+0.034097 x-0.000051 x^{2}\right.$; $\mathrm{R}^{2}=88.77 \%$ ). However, the emergence speed is constant for the seeds stored in the aluminum can throughout 720 days, showing the superiority of this packaging.

Table 6. Average values of initial emergence (IE) of pelleted tobacco seeds from the cultivar BAT 2101, stored for 720 days in different packages.

\begin{tabular}{lccccc}
\hline \multirow{2}{*}{ Packaging } & \multicolumn{5}{c}{ Periods (days) } \\
\cline { 2 - 6 } & 0 & 180 & 360 & 540 & 720 \\
\hline Cotton & $09 \mathrm{aD}$ & $62 \mathrm{bB}$ & $80 \mathrm{bA}$ & $68 \mathrm{cB}$ & $30 \mathrm{bC}$ \\
Aluminum can & $02 \mathrm{aC}$ & $88 \mathrm{aA}$ & $87 \mathrm{aA}$ & $91 \mathrm{aA}$ & $87 \mathrm{aA}$ \\
Laminated env. & $02 \mathrm{aD}$ & $87 \mathrm{aA}$ & $89 \mathrm{aA}$ & $78 \mathrm{bB}$ & $25 \mathrm{cC}$ \\
Plastic env. & $02 \mathrm{aD}$ & $83 \mathrm{aA}$ & $72 \mathrm{bB}$ & $73 \mathrm{bB}$ & $19 \mathrm{cC}$ \\
Paper env. & $03 \mathrm{aC}$ & $86 \mathrm{aA}$ & $76 \mathrm{aA}$ & $81 \mathrm{bA}$ & $31 \mathrm{bB}$ \\
\hline \multicolumn{1}{c}{$\mathrm{CV}(\%)$} & & & 10.17 \\
\hline
\end{tabular}

Averages followed by the same lowercase letter (in columns) or the same capital letter (in rows) do not differ by the Scott-Knott test at 5\% of probability.

Table 7. Average values of final stand (FS) of pelleted tobacco seeds from the cultivar BAT 2101, stored for 720 days in different packages.

\begin{tabular}{lccccc}
\hline \multirow{2}{*}{ Packaging } & \multicolumn{5}{c}{ Periods (days) } \\
\cline { 2 - 6 } & 0 & 180 & 360 & 540 & 720 \\
\hline Cotton & $70 \mathrm{aB}$ & $87 \mathrm{aA}$ & $93 \mathrm{aA}$ & $88 \mathrm{aA}$ & $82 \mathrm{aA}$ \\
Aluminum can & $79 \mathrm{aB}$ & $88 \mathrm{aA}$ & $91 \mathrm{aA}$ & $96 \mathrm{aA}$ & $91 \mathrm{aA}$ \\
Laminated env. & $84 \mathrm{aA}$ & $92 \mathrm{aA}$ & $92 \mathrm{aA}$ & $90 \mathrm{aA}$ & $67 \mathrm{bB}$ \\
Plastic env. & $78 \mathrm{aA}$ & $86 \mathrm{aA}$ & $91 \mathrm{aA}$ & $88 \mathrm{aA}$ & $62 \mathrm{bB}$ \\
Paper env. & $82 \mathrm{aA}$ & $88 \mathrm{aA}$ & $88 \mathrm{aA}$ & $89 \mathrm{aA}$ & $80 \mathrm{aA}$ \\
\hline \multicolumn{1}{c}{ CV (\%) } & \multicolumn{5}{c}{8.76} \\
\hline
\end{tabular}

Averages followed by the same lowercase letter (in columns) or the same capital letter (in rows) do not differ by the Scott-Knott test at $5 \%$ of probability.

Table 8. Average values of emergence speed index (ESI) of pelleted tobacco seeds from the cultivar BAT 2101, stored for 720 days in different packages.

\begin{tabular}{lccccc}
\hline \multirow{2}{*}{ Packaging } & \multicolumn{5}{c}{ Periods (days) } \\
& 0 & 180 & 360 & 540 & 720 \\
\hline Cotton & $08 \mathrm{bC}$ & $14 \mathrm{bA}$ & $13 \mathrm{aA}$ & $12 \mathrm{bA}$ & $10 \mathrm{bB}$ \\
Aluminum can & $08 \mathrm{bB}$ & $14 \mathrm{cA}$ & $14 \mathrm{aA}$ & $15 \mathrm{aA}$ & $15 \mathrm{aA}$ \\
Laminated env. & $09 \mathrm{aC}$ & $16 \mathrm{aA}$ & $14 \mathrm{aB}$ & $13 \mathrm{bB}$ & $08 \mathrm{cC}$ \\
Plastic env. & $09 \mathrm{aB}$ & $14 \mathrm{bA}$ & $14 \mathrm{aA}$ & $13 \mathrm{bA}$ & $07 \mathrm{cB}$ \\
Paper env. & $09 \mathrm{aB}$ & $14 \mathrm{bA}$ & $13 \mathrm{aA}$ & $14 \mathrm{bA}$ & $10 \mathrm{bB}$ \\
\hline \multicolumn{7}{c}{$\mathrm{CV}(\%)$} & & 8.78 \\
\hline
\end{tabular}

Averages followed by the same lowercase letter (in columns) or the same capital letter (in rows) do not differ by the Scott-Knott test at $5 \%$ of probability. 


\section{Conclusions}

The aluminum can packaging keeps the quality of bare and pelleted tobacco seeds from the cultivar BAT 2101 for a period of 720 days. Up to 360 days of storage, there was a decrease in the dormancy of bare and pelleted seeds with an increase in deterioration after this period, except for the seeds kept in the aluminum can packs.

\section{Acknowledgements}

To the Coordenação de Aperfeiçoamento de Pessoal de Nivel Superior (CAPES), to Conselho Nacional de Desenvolvimento Cientifico e Tecnológico ( $\mathrm{CNPq}$ ) and to the Fundação de Amparo à Pesquisa do Estado de Minas Gerais (FAPEMIG) for the financial support to perform the study and granting the scholarship. To the company Souza Cruz Ltda. for supplying the tobacco seeds and the commercial packages for conduction of the experiment.

\section{References}

AGACKA, M.; DEPTA, A.; BÖRNER, M.; DOROSZEWSKA, T.; HAY, F.R.; BÖRNER, A. Viability of Nicotiana spp. Seeds stored under ambient temperature. Seed Science and Technology, v.41, p.474-478, 2013. http://www.ingentaconnect.com/content/ista/sst/2013/.../art00015

AMARO, H.T.R.; DAVID, A.M.S.S.; ASSIS, M.O.; RODRIGUES, B.R.A.; CANGUSSÚ, L.V.S.; OLIVEIRA, M. Testes de vigor para avaliação da qualidade fisiológica de sementes de feijoeiro. Revista de Ciências Agrárias, v.38, n.3, p.383-389, 2015. http://www.scielo. mec.pt/pdf/rca/v38n3/v38n3a13.pdf

AZEVEDO, M.R.Q.; GOUVEIA, J.P.G.; TROVÃO, D.M.M.; QUEIROGA, V.P. Influência das embalagens e condições de armazenamento no vigor de sementes de gergelim. Revista Brasileira de Engenharia Agrícola e Ambiental, v.7, n.3, p.519-524, 2003. http://www.scielo.br/scielo.php?script=sci_ arttext\&pid=S1415-43662003000300019

BRASIL. Ministério da Agricultura, Pecuária e Abastecimento. Regras para análise de sementes. Brasília: Secretaria de Defesa Agropecuária, SNDA/DNDV/CLAV, 2009. 395p. http://extranet.agricultura.gov.br/ $\mathrm{php} /$ proton/cultivarweb/cultivares_protegidas.php

BELMIRO, T.M.; QUEIROZ, A.J.M.; FIGUEIREDO, R.M.F.; FERNANDES, T. K. S.; BEZERRA, M.C.T. Alterações químicas e físico-químicas em grãos de abóbora durante o armazenamento. Revista Brasileira de Engenharia Agrícola e Ambiental, v.14, n.9, p.1000-1007, 2010. http:/www.scielo.br/scielo.php?pid=S1415$43662010000900013 \&$ script $=$ sci_abstract\&tlng $=$ pt

CALDEIRA, C.M.; CARVALHO, M.L.M.; GUIMARÃES, R.M.; COELHO, S.V.B. Qualidade de sementes de tabaco durante o processo de pelotização e armazenamento. Ciência Rural, v.46, n.2, p.216-220, 2016. http://www.scielo.br/scielo.php?script=sci arttext\&pid=S0103-84782016000200216
CARDOSO, R.B.; BINOTTI, F.F.S.; CARDOSO, E.D. Potencial de armazenamento de sementes de cambre em função de embalagens e armazenamento. Pesquisa Agropecuária Tropical, v.42, n.3, p.272-278, 2012. http://www.scielo.br/scielo.php?script=sci_ arttext\&pid $=$ S1983-40632012000300006

CARVALHO, C.; NOVEMBRE, A.L.C. Avaliação da qualidade de sementes de fumo, nuas e revestidas, pelo teste de condutividade elétrica. Revista Brasileira de Sementes, v.33, n.1, p.177-185, 2011. http://www.scielo.br/scielo.php?pid=S010131222011000100020\&script $=$ sci_abstract\&tlng=pt

COSTA, L.M.; RESENDE, O.; GONÇALVES, D.N.; SOUSA, K.A. Qualidade dos frutos de crambe durante o armazenamento. Revista Brasileira de Sementes, v.34, n.2, p.239-301, 2012. http://www. scielo.br/scielo.php?pid=S0101-31222012000200015\&script $=$ sci_ abstract\&tlng=pt

FERREIRA, D.F. Sisvar: a computer statistical analysis system. CiênciaeAgrotecnologia, v.35,p.1039-1042,2011.http://www.scielo. br/scielo.php?script=sci_arttext\&pid=S1413-70542011000600001

LEE, Y.P.; BAEK, K.; LEE, H.; KWAK, S.; BANG, J.; KWON, S. Tobacco seeds simultaneously over-expressing $\mathrm{Cu} / \mathrm{Zn}$ superoxide dismutase and ascorbate peroxidase display enhanced seed longevity and germination rates under stress conditions. Journal of Experimental Botany, v.61, n.9, p.2499-2506, 2010. https://www. ncbi.nlm.nih.gov/pmc/articles/PMC2877901/

LEUBNER-METZGER, G. Seed after-ripening and over-expression of class I $\beta$-1,3-glucanase confer maternal effects on tobacco testa rupture and dormancy release. Planta, v.215, p.959-968, 2002. http://www.seedbiology.eu/pdf/planta02.pdf

LEUBNER-METZGER, G.; MEINS, F.J.R. Sense transformation reveals a novel role for class I b-1,3-glucanase in tobacco seed germination. Plant Journal, Oxford, v.23, n.2, p.215-221, 2000. http:// onlinelibrary.wiley.com/doi/10.1046/j.1365-313x.2000.00773.x/epdf

MAGUIRE, J.D. Speeds of germination aid selection and evaluation for seedling emergence and vigor. Crop Science, Madison, v.2, n.2, p.176-177, 1962. https://dl.sciencesocieties.org/publications/cs/ abstracts/2/2/CS0020020176/

MASSETO, T.E.; GORDIN, C.R.B.; QUADROS, J.B.; REZENDE, R.K.S.; SCALON, S.P.Q. Armazenamento de sementes de Crambe abyssinica Hochst ex. RE.Fr em diferentes embalagens e ambientes. Revista Ceres, v.60, n.5, p.646-652, 2013. http://www.redalyc.org/ $\mathrm{html} / 3052 / 305228952007 /$

NASCIMENTO, W.N.; SILVA, J.B.; SANTOS, P.E.C.; CARMONA, R. Germinação de sementes de cenoura osmoticamente condicionadas e peletizadas com diversos materiais. Horticultura Brasileira, v.27, p.12-16, 2009. http://www.scielo.br/pdf/hb/v27n1/03.pdf

OLIVEIRA, J.A.; PEREIRA, C.E.; GUIMARÃES, R.M.; VIEIRA, A.R.; SILVA, J.B.C. Efeito de diferentes materiais de peletização na deterioração de sementes de tomate durante o armazenamento. Revista Brasileira de Sementes, v.25, n.2, p.20-27, 2003. http:// www.scielo.br/pdf/rbs/v25n2/19645.pdf 
OLIVEIRA, E.M.; COSTA, C.C. Qualidade fisiológica de gergelim armazenado em diferentes condições de conservação. Engenharia Ambiental, v.6, n.3, p.395-403, 2009. http:// ferramentas.unipinhal.edu.br/engenhariaambiental/include/getdoc. php?id $=951 \&$ article $=325 \&$ mode $=$ pdf.

ONELLI, E.; MOSCATELLI, A.; GAGLIARDI, A.; ZANINELLI, M.; BINI, L.; BALDI, A.; CACCIANIGA, M.; REGGI, S.; ROSSI, L. Retarded germination of Nicotiana tabacum seeds following insertion of exogenous DNA mimics the seed persistent behavior. Plos ONE, v.12, n.12, p.1-32, 2017. http://journals.plos.org/plosone/ article?id=10.1371/journal.pone.0187929

PEREIRA, C.E.; OLIVEIRA, J.A.; ROSA, M.C.M.; KIKUTI, A.L.P. Armazenamento de sementes de braquiária peletizadas e tratadas com fungicida e inseticida. Ciência Rural, v.41, n.12, p.2060-2065, 2011. http://www.scielo.br/scielo.php?script=sci arttext\&pid=S0103-84782011001200004

PINTO JÚNIOR, A.S.; GUIMARÃES, V.F.; DRANSKI, J.A.L.; STEINER, F.; MALAVASI, M.M.; MALAVASI, U.C. Armazenamento de sementes de pinhão manso em diferentes embalagens e ambientes. Revista Brasileira de Sementes, v.34, n.4, p.636-643, 2012. http://www.scielo.br/scielo.php?pid=S0101$31222012000400015 \&$ script $=$ sci_abstract\&tlng $=$ pt
QUEIROGA, V.P.; CASTRO, L.B.Q.; GOMES, J.P.; SILVA, A.L.; ALVES, N.M.C.; ARAUJO, D.R. Qualidade fisiológica de sementes de algodão armazenadas em função de diferentes tratamentos e cultivares. Revista Brasileira de Produtos Agroindustriais, v.11, n.1, p.43-54, 2009. http://www.deag.ufcg.edu.br/rbpa/rev111/Art1117.pdf

RESENDE, M.L.; SILVA, T.T.A.; GUIMARÃES, R.M.; SILVA, E.A.A. Influência da luz e giberelina na velocidade de germinação das sementes de cafeeiro (Coffea arabica L.). Coffee Science, v.4, n.2, p.149-154, 2009. http://www.coffeescience.ufla.br/index.php/ Coffeescience/article/view/179

SILVA, F.S.; PORTO, A.G.; PASCUALI, L.C.; SILVA, F.T.C. Viabilidade do armazenamento de sementes em diferentes embalagens para pequenas propriedades rurais. Revista de Ciências Agroambientais Alta Floresta, v.8, n.1, p.45-56, 2010. http://www. unemat.br/revistas/rcaa/docs/vol8/5_artigo_v8.pdf

SINDITABACO. Sindicato da Indústria do Fumo da Região Sul do Brasil. Exportações. http://www.sinditabaco.com.br/sobre-o-setor/ exportacao/ Accesed on jan 22 2018. 